\title{
LOCAL CLIMATE CHANGE AND URBAN HEAT ISLAND MITIGATION TECHNIQUES - THE STATE OF THE ART
}

\author{
Hashem AKBARI ${ }^{\mathrm{a}}$, Constantinos CARTALIS ${ }^{\mathrm{b}}$, Denia KOLOKOTSA ${ }^{\mathrm{c}}$, Alberto MUSCIO ${ }^{\mathrm{d}}$, \\ Anna Laura PISELLO ${ }^{\mathrm{e}}$, Federico ROSSI ${ }^{\mathrm{e}}$, Matheos SANTAMOURIS ${ }^{\mathrm{b}}$, Afroditi SYNNEFA ${ }^{\mathrm{b}}$, \\ Nyuk Hien WONG ${ }^{\text {, }}$, Michele ZINZIg \\ ${ }^{a}$ Concordia University, 1455 De Maisonneuve Blvd. W., Montreal, Quebec, Canada \\ ${ }^{b}$ National and Kapodistrian University of Athens, 30 Panepistimiou Ave, \\ 10679 Athens, Greece \\ ${ }^{c}$ Technical University of Crete, University Campus, Akrotiri 73100 Chania, Greece \\ ${ }^{d}$ University of Modena and Reggio Emilia, Via Università, 4, 41121 Modena MO, Italy \\ ${ }^{e}$ University of Perugia, Piazza Università, 1, 06100 Perugia, Italy

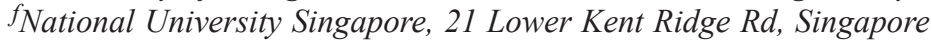 \\ ${ }^{g}$ ENEA: Italian National Agency for New Technologies, Energy and Sustainable Economic Development, \\ Lungotevere Thaon di Revel, 76-00196 Rome, Italy
}

Received 05 Sep 2015; accepted 14 Oct 2015

\begin{abstract}
Increase of the ambient air temperature in cities caused by the urban heat island phenomenon has a serious impact on the economic and social system of cities. To counterbalance the consequences of the increased urban temperatures important research has been carried out resulting in the development of efficient mitigation technologies. The present paper aims to present the state of the art in terms of local climate change and urban heat island mitigation techniques. In particular, developments in the field on highly reflective materials, cool and green roofs, cool pavements, urban green and of other mitigation technologies are presented in detail, while examples of implemented projects are given.
\end{abstract}

Keywords: urban heat island, mitigation, adaptation, cool materials.

\section{Introduction to the main problems and challenges in the urban environment}

The world's cities occupy just 2 per cent of the Earth's land, but account for $60-80 \%$ of energy consumption and $75 \%$ of carbon emissions. They also reflect interlinked problems such as urbanization, degradation of the thermal environment, land uptake, poor building stock and climate change (EEA 2012, 2013, 2015; ICLEI 2013; IPCC 2014). In particular, IPCC (2014) refers to the impact of climate change to cities, mostly in terms of the increase of surface air temperature as well as, of the increased occurrence of heat waves. In cities with increasing surface and near surface air temperatures (warming cities), heat waves are expected to increase in frequency, intensity and duration (Meehl, Tebaldi 2004; EEA 2010). Actually, a multi-fold relationship controls the link of urban environments to climate change (EEA 2010; Kamal-Chaoui, Alexis 2009; Stone et al. 2012): cities are major contributors to $\mathrm{CO}_{2}$ emissions; cities consume a great majority - between 60 to $80 \%$ - of energy produc- tion worldwide and account for a roughly equal share of global $\mathrm{CO}_{2}$ emissions; climate change poses key threats to urban infrastructure and quality of life due to rising sea levels, more extreme storms and flooding, extreme heat events and local drying of soils.

Continuing population growth and urbanization are projected to add 2.5 billion people to the world's urban population by 2050 , with nearly $95 \%$ of urban expansion in the next decades to take place in the developing world. The fastest growing urban agglomerations are mediumsized cities and cities with less than 1 million inhabitants located in Asia and Africa. Most megacities and large cities are located in the global south. The number of megacities have nearly tripled since 1990; by 2030, 41 urban agglomerations are projected to house at least 10 million inhabitants each (United Nations 2014). In Europe alone, at present, nearly $73 \%$ of the European population live in cities, and this is projected to reach $82 \%$ in 2020 (EEA 2010).

Corresponding author: Matheos Santamouris

E-mail:msantam@phys.uoa.gr 
Urbanization is associated with changes in energy fluxes which once occurring may result in changes of the microclimate as well as, in the degradation of the thermal environment; it also contributes to climate change due to the increased emissions of greenhouse gases. In addition urbanization leads to urban land take and excess building stock, frequently made of building materials of poor thermal characteristics. According to several researchers (Stone et al. 2010; Kolokotroni et al. 2010; Grimmond 2011; Santamouris et al. 2015a, 2015b) the long term trend in surface air temperature in urban centres is associated with the intensity of urbanization.

Many cities worldwide experience the presence of the urban heat island (UHI), namely higher surface or air temperatures in the city centers as compared to the surrounding countryside. The intensity of the UHI depends strongly on the urban characteristics, the synoptic conditions, the local meteorological features, the type of urban materials and the presence (or lack) of green areas. Furthermore, artificial heating and cooling of buildings, transportation and industrial processes introduce anthropogenic sources of heat into the urban environment causing distinct and even enhanced UHIs (Wilby 2007), with their intensities showing an overall increase with the years. In some cities differences may even reach 6 to $10 \mathrm{~K}$ (Santamouris 2015a, 2015b) while the higher the population density and the lower the share in green and blue areas, the higher the intensity of the UHI. Urban heat island is present at any latitude and may occur during the day or night as a function of the local thermal balance. Its magnitude increases during the calm and clear days while it is highly affected by sea breeze and precipitation, (Santamouris 2015a).

Urban heat island has a serious impact on the quality of life of urban citizens. It increases the energy consumption for cooling purposes, increases the peak electricity demand during the summer period, deteriorates indoor and outdoor thermal comfort, increases the concentration of harmful pollutants like the tropospheric ozone, and has a serious impact on the health conditions of the vulnerable urban population (Santamouris 2015b).

Housing infrastructure is vulnerable to extreme weather events which may be caused due to climate change. In practical terms, poor urban design can enhance the impacts of climate change, whereas buildings that were originally designed for certain thermal conditions may need to operate in drier and hotter climates in the future (WHO 2008). Finally, how cities grow and operate matters for energy demand and thus for GHG emissions. To this end important issues to examine are as diverse as urbanization, urban sprawl and compact city development.

\section{Facing the urban heat island, mitigation strategies}

The last three decades have witnessed significant research and development activities in understanding urban heat islands, their environmental effects, their health impacts, development of measures to mitigate heat islands, and development of implementing policies and programs to cool urban heat islands. The research was initially focused on recognizing that the cities are warmer than their suburban areas, noting that these elevated temperatures are because of urban fabric, and investigating the potential changes in the urban fabric, (changing urban surfaces and adding urban vegetation), would affect the summertime energy use in urban buildings (Akbari 1992). The research identified that cool roofs and shade trees directly reduce cooling energy use in buildings and combination of cool roofs, cool pavements, and urban vegetation will cool the city by a few degrees (Akbari 1992). Cooling cities, (lower ambient temperatures), further decreases cooling energy use in buildings, make the outdoor pedestrian environment more comfortable, and slow down the smog photochemical reactions (see Fig. 1). Cool roofs and shade trees reduce air conditioning energy use leading a lower

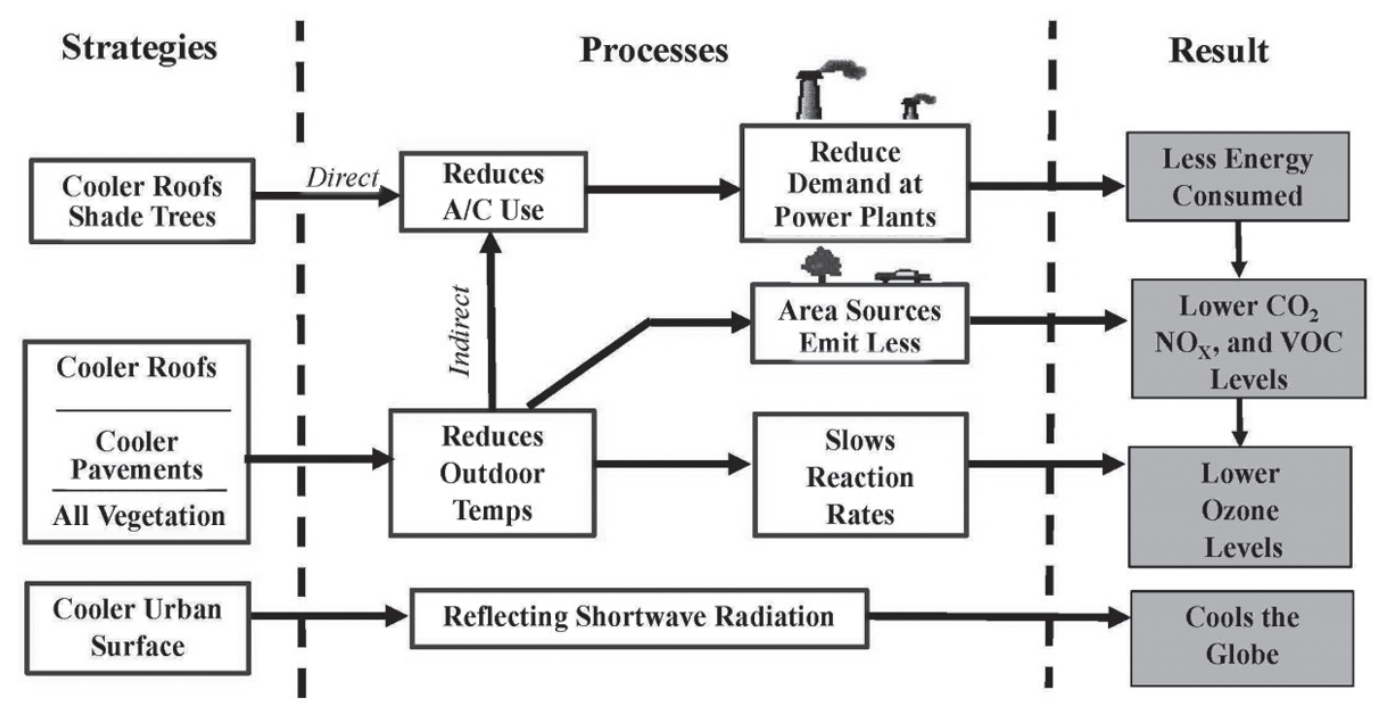

Fig. 1. Effects of heat island countermeasures 
demand for power, lower consumption of fuel, lower air pollutants and greenhouse gas emissions. Cool roofs, cool pavement, and urban vegetation cool the city and reduce formation of smog. Cool roofs and cool pavements reflect shortwave radiation back to space and induce a negative radiation forcing. These initial findings lead to an explosion of research and public interest in cooling urban heat islands.

Building energy simulations in many climates quantified the potential cooling energy savings and electrical peak demand reductions in many climates in the U.S. and worldwide. Simulations also allowed quantifying the potential heating energy penalties during winter (Synnefa et al. 2007a). The analysis concluded that cool roofs saves the energy consumption related annual expenditures in all buildings that need cooling during the summer and winter heating penalties are only a fraction of summer cooling savings. In some climates, installing a cool roof precludes the need to buy air conditioning. These simulations were validated with many field experiments documenting cooling energy savings of $10-50 \%$ (depending on climate, building type and operation) for the area under the roof (Synnefa et al. 2012).

Meteorological and air quality simulations concluded that a modest program in increasing the reflectivity of urban surfaces and increasing urban vegetation can potentially reduce the average urban temperature during the hot summer days by about $3 \mathrm{~K}$ (Taha 2008). Some simulations showed that the reduction in smog concentration during the simulated period was as significant as the combination of all the air quality control measures considered to improve urban air quality. In addition, this $3{ }^{\circ} \mathrm{C}$ reduction in ambient temperature can improve pedestrian ambient comfort and have a significant effect in reducing heat stress related health problems during the summertime heat storms (Pantavou et al. 2011). More recent studies have focused on analysis of urban climate both at regional and community scale. Such studies lead to providing the needed information to the policy makers for design of effective policies to reduce urban heat island and their detrimental effects (Fintikakis et al. 2011).

To further characterize the urban heat islands several studies used historical meteorological data (temperature, humidity, wind speed); these studies were performed for a number of cities around the world. In addition, customized high resolution orthophotographic data were gathered to characterize fabric of several cities in the U.S. The study demonstrated that, under tree canopy, roofs and pavements constitute about $25 \%$ and $35 \%$ of a typical American city. Also the tree cover in most cities was less than $25 \%$. It is expected in denser cities such as Tokyo, New York City, Honk Kong, the combined fraction of roof and pavement area may approach $90 \%$.

The potential benefits of cool roofs and heat island measures were further investigated in cold climates (Hosseini, Akbari 2014; Mastrapostoli et al. 2014). The moisture transfer in roofing layers were studied and concluded that roofs were not different from walls in terms of their moisture transfer. Installing a cool roof does not create moisture problems on properly engineered design and constructed to the code. In addition, accumulated snow on the roof significantly reduces potential winter heating penalties in cold climates (a white and a black roof covered with snow perform the same).

More recent studies have quantified the effect of cool roofs and cool pavements (reflective surfaces) in inducing a negative radiative forcing and countering the global warming. The 2014 IPCC $5^{\text {th }}$ Assessment Report (AR5) states that "...changing the solar reflectance of a dark roof (0.15) to an aged white roof (0.55) results in a one-time offset of 1 to $2.5 \mathrm{tCO}_{2}$ per $10 \mathrm{~m}^{2}$ of roof area through enhanced reflection. Global $\mathrm{CO}_{2}$ one-time offset potentials from cool roofs and pavements amount to 78 $100 \mathrm{GtCO}_{2}$. Increasing the albedo of a $1 \mathrm{~m}^{2}$ area by 0.01 results in a global temperature reduction of $3 \times 10^{-15}{ }^{\circ} \mathrm{C}$ and offsets emission of $7 \mathrm{~kg} \mathrm{CO}_{2}$ " (Akbari et al. 2012).

Since early 1990, efforts have focused to develop durable reflective roofing and paving materials. The initial focus was to develop white roofing materials including white roof coatings. Later the focus extended to develop cool coloured roofing materials that reflect the near infrared (NIR) solar radiation. These technologies quickly found their ways to the market; many manufactures produce durable white roofing materials and cool coloured roofings available for coating, tiles, painted metals, and fiberglass asphalt shingles (Akbari, Matthiews 2012). Research has further been extended to develop thermochromics roofing materials that become more reflective at higher temperatures, directionally reflective materials that are reflective to the sun's rays and look dark from streets and retro-reflective materials that reflect the light specularly in the direction of the sunlight (Kolokotsa et al. 2013a). Roof gardens and wet roofs have been also studied in reducing the building cooling energy use, while offering other amenities (Kolokotsa et al. 2013b).

The development of cool pavements has been more challenging. Studies have characterized many paving materials and paving surface technologies such as chip seals, white topping, coloured concrete, grasscrete, and permeable pavements for water drainage. These cool paving technologies are currently used in many specific applications.

\section{The energy impact of urban heat island an local climate change}

Urban heat island may produce a sensible impact on the energy consumption of several urban facilities, utilities and transportation system. The most documented effect of UHI is related to a significant increase of the peak and global electricity demand for HVAC systems and also an important decrease in the performance of the air conditioning systems.

The UHI induced power and energy increase typically depends on the magnitude of urban warming, local 
climate conditions and characteristics of the buildings and HVAC systems. Akbari (1992) reported that the peak electricity load in U.S. cities with populations larger than 100,000 will increase $1.5-2 \%$ for every $0.45^{\circ} \mathrm{C}$ increase in temperature. In parallel, Santamouris et al. (2001), using climatic measurements from 30 urban and suburban stations in Athens, Greece, estimated the impact of UHI on the energy consumption of buildings and found that the cooling load downtown Athens is double compared to the surrounding region. Moreover the peak electricity demand is tripled, while the heating load may be reduced up to $30-50 \%$ in the urban area. Additionally UHI produces a change on performances of electrical and mechanical devices, reducing the Coefficient of Performance (COP) of mechanical cooling systems up to $25 \%$.

Santamouris (2014a) collected and compared many surveys identifying two kinds of approaches: the first one compares the energy needs of reference buildings in urban and rural locations; the second one evaluates energy increase caused by UHI via time historical data analysis. The most important investigated parameters were the peak and the total electricity demand. Data available for Tokyo, Thailand, Ontario East Canada, Los Angeles, Washington, Dallas, Colorado Springs, Phoenix and Tuscon, Israel and Carolina, USA, showed that one degree temperature increase determines a $0.45-4.6 \%$ increase of peak electricity change (Santamouris et al. 2015a). This fact causes $21 \mathrm{~W} /{ }^{\circ} \mathrm{C}( \pm 10.4)$ additional electricity penalty per person. The change on hourly, daily, monthly electricity demand due to UHI was also worked out: electricity demand increases from $0.5 \% /{ }^{\circ} \mathrm{C}$ for countries as Netherlands to $8.5 \% /{ }^{\circ} \mathrm{C}$ for Louisiana and Maryland, USA, with an average value close to $4.6 \% /{ }^{\circ} \mathrm{C}$. The total energy budget of buildings changes from cooling dominated zones to heating dominated zones. In the first case, the UHI generally produces an increase in energy demand for cooling higher than the corresponding reduction of the heating demand. In heating dominated zones, the UHI reduces the energy demand for heating and annual energy more than the corresponding increase of the cooling demand. It is reported that, for most of the cases, the threshold ambient temperature over which cooling energy demand overtakes energy saving for heating is $18^{\circ} \mathrm{C}$ (Santamouris 2014a).

In parallel, existing analysis regarding the additional energy consumption for cooling purposes induced by the UHI, indicate that the Global Energy Penalty per unit of city Surface (GEPS) changes between 1.1 and $5.5 \mathrm{kWh} / \mathrm{m}^{2}$, while the Global Energy Penalty per Person (GEPP) varies between 104 and $405 \mathrm{kWh} / \mathrm{p}$ (Santamouris 2014a).

The temporal variation of the heating and cooling load of typical buildings caused by the global and local climate change for the period 1970-2010 is also studied by Santamouris (2014). The analysis demonstrated that the combined effect of the local and global climate change causes an average increase of the cooling demand as $23 \%$, and a corresponding average reduction for heating of $19 \%$. A balance showed that average overall energy increase for heating and cooling is $11 \%$.

\section{Impact of urban overheating on the environment, health, comfort and economy}

Urban overheating produced by UHI has a dangerous impact on citizens' health conditions and indoor-outdoor comfort perception, affecting their quality of life and economic wellbeing and, therefore, having a non-negligible modification of the urban environment from multiple perspectives (Kolokotsa, Santamouris 2015). In particular, the most sensitive people to this environmental change are low income and vulnerable population living in dense urban areas (Sakka et al. 2012; Santamouris et al. 2014). Sakka et al. (2012) showed that the extended exposure to hot thermal conditions, as registered during the heat wave of 2007 in South-Eastern Europe, produced dangerous indoor thermal overheating in buildings with low technical quality, in particular. More in details, the authors measured that the average indoor temperature of all the monitored residential units was almost $4.2^{\circ} \mathrm{C}$ higher than the average indoor temperature registered in standard summer conditions in Athens, i.e. before and after such heat wave period, exacerbated by UHI in Athens. Indoor thermal field measurements showed how the heat wave emphasized by UHI made people exposed to hot spells above $33{ }^{\circ} \mathrm{C}$ for 6 days continuously, provoking not only low indoor comfort issues, but also increasing the risk of non-negligible health disease for the most vulnerable households (Sakka et al. 2012). Consistent provisional results achieved by means of the thermal-energy models developed within the framework of LUCID projects (Mavrogianni et al. 2011) showed that the number of indoor overheating hours (operative temperature higher than $28{ }^{\circ} \mathrm{C}$ ) tends to increase while approaching another European megacity affected by UHI, i.e. London greater area, demonstrating the necessity to take into account of UHI-affected weather conditions while analyzing indoor thermal comfort in buildings.

In fact, outdoor urban environment overheated by UHI demonstrated to hugely affect indoor thermal conditions, especially in those buildings that are characterized by low quality envelope and no HVAC system for active cooling (Sakka et al. 2012). Additionally, the relatively low awareness and education level of low income households with respect to the correct use of passive cooling strategies for improving indoor thermal conditions make them even more vulnerable against summer heat wave events and UHI in general. In this view, key research contributions were focused on the identification of UHI effect on energy poor population, where the core of the analysis was focused on the impossibility of households to provide for the necessary environmental active systems, aimed at addressing cooling and heating elementary needs (Santamouris et al. 2012; Plan Batiment Grenelle 2009). In this view, statistics also showed that energy poor people are used to live in buildings characterized by low quality performance envelope mainly produced by poor thermal insulation and inertia, non-effective shading systems and high infiltration rate (Plan Batiment Grenel- 
le 2009). Therefore, the combination of energy poverty and weak availability of effective passive systems make low-income households even more vulnerable against the UHI phenomenon in dense cities all over the world. Furthermore energy poor European population spends about $40 \%$ of their total income on housing running costs, that is $30 \%$ more than the average European population (Kolokotsa, Santamouris 2015).

Mortality increases in hot weather especially amongst the most vulnerable ones, including the elderly. During the major European heat wave of 2003, urban centres, such as Paris, were particularly affected due to extreme day temperatures (Tobias et al. 2010). The strength of the relationship between daily outdoor temperature and health outcomes differs between countries, between cities and even in the same location from one year to the next (WHO 2008; Baccini et al. 2011). In general, people typically display an optimum temperature at which the death rates are lowest; mortality rates rise with temperatures beyond this temperature. In particular, mortality for populations in the European Union has been estimated to increase by 1 to $4 \%$ for each degree increase of temperature above a (locally specific) cut-off point (WHO 2011). Key studies conducted in the UK (Mavrogianni et al. 2011) shown that extreme urban overheating events are expected to be exacerbated in urban areas due to UHI phenomenon. For instance, in England and Wales the excess in heat-related deaths has showed to be about $17 \%$ during the 2003 heat wave summer period (Mavrogianni et al. 2011).

Urban air pollution concentrations increase in warming cities (Stathopoulou et al. 2008; Taha 2008); they may also increase during heat waves with significant consequences for mortality as in Paris in the summer of 2003. This is due to the fact that high temperatures and solar radiation stimulate the production of ozone as well as volatile organic compounds (VOCs). Under existing air pollution abatement policies 311,000 premature deaths are projected in 2030 due to ground-level ozone and fine particles (EEA 2006).

\section{Mitigating the urban heat island - overview of the main technologies}

\subsection{Development of reflective materials}

Materials used in the urban fabric play a very important role in the urban thermal balance as they absorb incident solar and infrared radiation and dissipate a percentage of the accumulated heat through convective and radiative processes in the atmosphere increasing ambient temperatures. Therefore, the use of "cool materials" on building envelopes and open spaces that can reflect a significant part of solar radiation and dissipate the heat they have absorbed through radiation, contribute to increasing the urban albedo, maintaining lower surface temperatures and thus present an effective solution to mitigate urban heat islands. The research in the field of solar reflective materials has been very active the past few years and has led to the development of innovative materials and techniques that present advanced radiative properties and improved thermal characteristics resulting in significant heat island mitigation potential (Santamouris et al. 2011).

Visible light $(0.4-0.7 \mathrm{~mm})$ contains $43 \%$ of the power in the air-mass 1.5 global solar irradiance spectrum $(0.3-2.5 \mathrm{~mm})$; the rest arrives as near-infrared (NIR) radiation $(0.7-2.5 \mathrm{~mm}, 52 \%)$ or ultraviolet (UV) radiation $(0.3-0.4 \mathrm{~mm}, 5 \%)$. A clean, smooth, and solar-opaque white surface (e.g. a white coating or single ply membrane) strongly reflects both visible (hence the bright white colour) and NIR radiation, achieving a solar reflectance of about 0.85 . This is the coolest type of roofing or paving surface. Most bright white materials are able to achieve their high solar reflectance mainly by using titanium dioxide $\left(\mathrm{TiO}_{2}\right)$ a pigment that reflects the energy in nearly all the sun's wavelengths (Gartland 2008). Other technologies proposed by researchers include the use of lime (calcium hydroxide), known traditionally for its whiteness, as the main component in combination with a specially designed acryl binder, to develop a cool white coating enhancing the solar reflectance of the external surface of buildings and concrete pavements (Santamouris et al. 2008) as well as white or light colour plaster that is used in vertical surfaces. Apart from white coatings and single ply membranes, other types of roofing and paving materials can become cooler using different technologies. For example, appropriate type of cool white/light coloured coatings can be added as surface layers to a wide range of traditional roofing materials such cap sheet or gravel over built up roofing, modified bitumen, various single ply materials, tiles and metals, and convert them to cool options. Cool white clay tiles have been developed using common ceramic tile industry production materials and processes by developing a white globe with high solar reflectance covered by a white gloss glaze (Ferrari et al. 2013; Pisello et al. 2013; Pisello, Cotana 2014). In order to create cool white shingles, increasing the solar reflectance of their covering granules or applying an appropriate cool white topcoat have been proposed (Gartland 2008). Another category of light coloured solar reflective materials is aluminium coatings, silver in colour, that contain aluminium flakes in an asphalt-type resin. Aluminium flakes enhance the solar reflectance to above 0.5 for the most reflective coatings and although such value is significantly higher compared to the performance of a black material $(\mathrm{SR}=0.05)$, the aluminium content has the offsetting effect of lower infrared emittance ranging usually from 0.25 to 0.65 (Synnefa et al. 2006).

In an effort to avoid glare problems but also to meet aesthetic preferences researchers have developed cool coloured products that are usually applied on steep slope roofs or other visible surfaces. A cool coloured surface is a surface that absorbs in the visible part of the spectrum in order to appear having a specific color and is highly 
reflective in the near infrared part of the spectrum. This results in an overall higher solar reflectance compared to a coloured surface of the same colour (same visible reflectance) that absorbs also in the near infrared part, taking into around that about $50 \%$ of the solar radiation falls in the NIR part of the spectrum. Several techniques have been used by researchers in order to develop solar reflective materials that have high near infrared reflectance. These techniques are based mainly on the use of specialized, complex inorganic colour pigments that are dark in colour but have the ability to reflect strongly in the near infrared (NIR) portion of the solar spectrum and are available in a wide range of colour shades from yellow to black (Levinson et al. 2005a, 2005b). Research in the field of synthesizing NIR reflective inorganic pigments, especially pigments that are environmentally friendly, using different methodologies has been very active the past few years as the demand for cool coloured products is increasing (Zheng et al. 2015). Replacing conventional NIR absorbing pigments in coatings by cool pigments that have the ability to reflect more near-infrared radiation can lead to the development of coatings that have similar colours and yet higher solar reflectance and therefore improved thermal performance (Synnefa et al. 2007b; Zinzi 2014). Depending on the NIR reflectance of the substrate, two techniques have mainly been used to create cool coloured materials: a) A one-coat (substrate/ topcoat) system that consists of applying a topcoat with pigments that weakly absorb and (optionally) strongly backscatter NIR radiation on a substrate that has originally high NIR reflectance; b) a two-coat (substrate/ basecoat/topcoat) system that consists of applying a cool topcoat (with pigments that weakly absorb NIR radiation) on a NIR reflecting basecoat (e.g. one coloured with titanium dioxide rutile white) if the substrate is characterized by low NIR reflectance (Levinson et al. 2007). Based on this technology many researchers have developed innovative cool coloured materials for the building envelope (Qin et al. 2014) and other surfaces of the urban environment (Synnefa et al. 2011).

Thermochromism is the property of substances to change their colour due to a change in temperature. Thermochromic materials, respond thermally to their environment, changing reversibly their colour from darker to lighter tones as temperature rises. The transition is achieved by a thermally reversible transformation of the molecular structure of the pigments that produces a spectral change of visible colour. A lot of materials have been investigated in searching for thermochromic pigments. The technology relays on organic leuco-dye mixtures based on three main components which are: the colour former, the colour developer (usually a weak acid that causes the reversible colour switch and colour intensity of the final product) and the solvent. The mixture is encapsulated in microcapsules to protect the thermochromic system from the chemicals around. Researchers have used this technology to develop thermochromic materials for the urban fabric (Karlessi et al. 2009). The main problem regarding the application of thermochromic materials in building envelopes and urban structures is photo degradation because even for short outdoor exposure, interaction with solar radiation causes the breaking and/or crosslinking of the polymer chains, leading to altered chemical and mechanical properties, and loss of the reversible thermochromic effect. Research aiming to solve this problem involves the use of UV absorbers and UV and optical filters and is still ongoing (Karlessi, Santamouris 2013).

Solar reflectance of roofing materials is a function of irradiance magnitude and direction, and surface properties. Recently, some directionally reflective materials have been developed and are commercially available. These are innovative products that have multifaceted surfaces whose colour and reflectance change with the surface orientation and thus the direction of incident solar radiation. They reflect sunlight (by reflective side) during summer (when the sun is high in sky) and absorb sunlight (by absorptive side) during the winter (when the sun is low). By design directional reflective look dark from the street and light from the sky (Akbari, Touchaei 2014). Another aspect of directional reflectivity is retro reflectivity which refers to the ability of a specially engineered surface to preferentially reflect incident light back towards its source regardless of the direction of incidence. The use of retro reflective materials, i.e. materials that mostly reflect the incident radiation in the same direction of the incoming radiation on the building envelope has been shown to be effective in reducing the reflected heat of the sun in the directions of neighboring roads and buildings and can be used as building materials to reduce urban heat island effect (Rossi et al. 2014, 2015).

In an effort to further decrease the temperature of solar reflective materials, researchers have combined latent heat storage materials with solar reflective materials. This has been done either by incorporating/doping latent heat materials into the cool materials or by combining the latent heat materials with the cool materials in order to create composite solar reflective material with latent heat properties. The first technology mainly involves doping microencapsulated phase change materials ( $\mathrm{PCMs}$ ) into solar reflective (white or NIR reflective) coatings (Karlessi et al. 2011). PCMs offer a large energy storage density and a nearly isothermal nature of the storage process during which PCMs undergoes a change of phase. The thermal energy transfer occurs when a material changes from solid to liquid, or liquid to solid. Heat storage and its recovery occur isothermally, preventing temperature swings Microencapsulation provides increasing heat transfer area, reduction of PCMs reactivity towards the outside environment and control of the changes in the storage material volume as phase change occurs thus improving the performance of the PCM. Microcapsules include an organic or inorganic phase change ingredient in their core and a polymer exterior shell. There are different melting temperatures according to the application 
requirements. For building/urban fabric applications organic PCMs are preferred mainly due to their chemical stability and high heat of fusion (Karlessi et al. 2011). When the ambient temperature is high (e.g. during a hot summer day) the PCM absorbs part of the heat through the melting process and when ambient temperature drops (e.g. during the cooler night time), the PCM solidifies and releases the stored heat. The net effect is a reduction of the daytime surface temperature of the material and therefore the reduction of the heat flow from the surface to indoor space and from surface to the ambient environment. During the night period, latent heat released by the PCM material has not an important impact of the surface temperature of the coating (Karlessi et al. 2011). PCMs used in building structures have the potential to reduce and delay the peak heat load leading to important energy savings and improvement of thermal comfort conditions (Karlessi et al. 2011).

\subsection{Development of cool roof technologies}

Cool roofs are solutions highly reflective of solar radiation due to their high solar reflectance, or albedo. They can prevent overheating of both individual buildings and entire urban areas. Their potential was quantitatively investigated since the eighties of the last century in California and other States of the U.S. (Taha et al. 1989), in response to both the UHI effect and the need of reducing energy and peak power for air conditioning. Many studies have followed, for instance evidencing the usefulness of increasing gradually the albedo of a city by choosing high-albedo surfaces to replace darker materials during routine maintenance of roofs, as well as that of establishing sponsored incentive programs, product labelling, and standards to promote the use of high-albedo materials for buildings (Rosenfeld et al. 1995). Strong savings of cooling energy and peak power were shown (Akbari et al. 1999), surveys on cool roofing materials for the U.S. were made, and the researchers also started to pay attention to the long-term performance of high-albedo roof coatings. Steps were then taken by cities in the warm half of U.S. towards incorporation of cool roofs in the revised ASHRAE building standards and inclusion of cool surfaces as tradeable smog-offset credits in Los Angeles, eventually culminating in prescriptive requirements such as the inclusion of cool roofs in energy codes like Title 24 of California Code of Regulation (Levinson et al. 2005c).

From the U.S. cool roof technologies have spread worldwide. Among the others, studies evidencing their potentialities have been made in Europe (Synnefa et al. 2006, 2007a) and the Cool Roofs Project has been cofunded by the European Union to promote high-albedo surface as a heat island mitigation strategy and a measure for reducing cooling loads (Synnefa, Santamouris 2012).

Two different families of cool roofing solutions can be identified: cool white technologies for flat roof coverings which are the ones more commonly used, and cool colour technologies for sloped roofs. The latter ones are designed to show a reflection spectrum in the visible range $(0.4-0.7 \mu \mathrm{m})$ as needed to obtain a desired colour, but at the same time high capacity of reflection in the near infrared (NIR, 0.7-2.5 $\mu \mathrm{m}$ ), where more than 50\% of solar radiation falls but it is invisible to the human eye.

Cool white roofing solution can be of many types: field applied coatings (paints, fluid applied membranes, etc.), reinforced bitumen sheets made of modified bitumen (elastomeric or plastomeric), single-ply sheets and membranes (thermoset or thermoplastic), tiles (ceramic, concrete, etc.), asphalt or bituminous shingles, pre-painted metal roofs, built-up roofing. They can show initial solar reflectance as high as $80-85 \%$ and thermal emittance usually in the range from $80 \%$ to $95 \%$ for non-metallic materials. Their white colour is the result of a high capacity of reflection in the visible range, but a similar capacity is needed in the near infrared to achieve a high value of the reflectance. In order to achieve a high reflection over the whole solar spectrum, cool roof technologies exploit white pigments such as titanium dioxide $\left(\mathrm{TiO}_{2}\right)$. The pigments can be dispersed in organic matrices such as acrylic or bituminous binders, but also in inorganic binders such as ceramic tiles and coatings. It is interesting to observe that a high solar reflectance may be the result of the mean of very different reflection spectra, weighted by the solar irradiance spectrum. On the other hand, it is very difficult to retain the initial reflectance value due to chemical and physical degradation of materials, biological growth and, above all, soiling caused by pollutant deposition. In fact, being the reflectance that of the most superficial matter, a superposed layer of particulate or other atmospheric suspensions may strongly affect the reflective performance. Therefore, aged values of solar reflectance are also provided in the framework of the CRRC rating program, obtained by natural exposure in three locations with different climate for at least three years (Sleiman et al. 2011). More recently, a method for accelerated aging has been developed, able to condense in three days of laboratory testing a three-year long natural aging due to soiling (Sleiman et al. 2014).

The development of matrices and white pigments chemically and physically stable permits to avoid degradation of the reflectance such as that associated to yellowing of the surface, whereas biocides can be used to limit biological growth, an issue arising in humid climates due to the low surface temperatures of cool roofs and persistent condensation of atmospheric moisture. In order to reduce soiling, several approaches are exploited such as controlling the surface porosity and roughness, possibly applying super-hydrophilic or super-hydrophobic surface treatments, or self-cleaning coatings based on photo-catalysis (Diamanti et al. 2013). Nonetheless, the most important requirement to limit degradation of cool white roofs is that a slope ensuring storm water runoff is adopted, and areas of stagnation are carefully avoided.

Cool colour technologies are being developed for roof surfaces whose colour is forced by landscaping con- 
straints such as for tile roofs in the centers of historical cities, or possibly by architectural choices. Solutions can be based on the choice of proper pigments with selective reflection (Levinson et al. 2005a, 2005b; Synnefa et al. 2007a), or by an effective approach based on a multilayered coating (Levinson et al. 2007), in which a white, highly reflective basecoat is applied to a substrate, and a topcoat with selective transparency is then applied to the basecoat, obtained by adding proper pigments to a transparent matrix. Cool colour technologies can be applied to either roofs or facades and other building surfaces not oriented skywards, but the presence of buildings that face each other and form the so-called urban canyon can cause the radiation that enters the canyon to bounce back and forth several times and not re-emerge (Takebayashi, Moriyama 2012).

\subsection{Development of cool pavement technologies}

Pavements influence highly the urban climate and contribute substantially to the development of the Urban Heat Island phenomenon. Pavements in most countries of the developed world are from asphalt or concrete and cover a rather high part of the urban areas. Studies in the United States indicate that pavements occupy almost $29 \%$ of the urban areas (Rose et al. 2003), while paved surfaces cover almost $29 \%$ to $39 \%$ when viewed above the urban canopy (Akbari, Rose 2001).

The thermal balance of paved surfaces is determined by the magnitude of the absorbed short wave radiation, the emitted and absorbed long wave radiation, the convective heat transfer, the gains and losses to the ground through conduction and the evaporation and condensation processes. The magnitude of the infrared radiation emitted by pavements may be very high and in Tokyo, Japan, according to Asaeda et al. (1996), it is almost equal to the half of the rate of the energy consumption of the commercial areas in the city.

Decrease of the sensible heat released by pavements in the atmosphere requires a decrease of their surface temperature. This can be achieved through the following techniques (Santamouris 2013):

a) By increasing the albedo of the pavements. Higher surface albedo of the paving surfaces decreases the absorbed solar radiation and decreases the surface temperature. Many techniques have been proposed either for the rehabilitation of the existing pavements or for new paving surfaces. Among other, the more used techniques involve resin based pavements, use of light aggregates in asphaltic and concrete pavements, the use of additives like fly ash and slag cement, the use of chip or sand seals, the use of colourless reflective binders, the use of sand/shot blasting and abrading binder surfaces, microsurfacing techniques, etc. In particular, Asphalt pavement can be modified with high albedo materials i.e. light-coloured aggregate, colour pigments, or sealants, or treated after installation to raise albedo with maintenance applications such as chip seals (made with high-albedo aggregate used to resurface asphalt roads and highways) white topping (a layer $>10 \mathrm{~cm}$ (white topping) or $<10 \mathrm{~cm}$ (thin white topping) of concrete applied over existing asphalt and microsurfacing (a thin sealing layer with high albedo materials used for road maintenance), concrete pavements that consist of cement, water and aggregates can have increased solar reflectance by using white cement instead of grey cement mixtures. New technologies proposed to increase the albedo of paved surfaces include: the use of white high reflective paints on the surface of the pavements, the use of infrared reflective colour paints on the surface of the paved materials, the use of heat reflective paints to cover the aggregates, and the use of colour changing paints on the surface of the paved zones (Santamouris 2013).

b) By increasing the permeability of the pavements in order to enhance the evaporation processes. This type of pavements is known as porous, permeable, pervious or water retaining. Vegetative pavements present a lower surface temperature because of the increased evapotranspiration and include grass pavers and concrete grid surfaces that allow grass to grow in the interstices. Non vegetative porous pavements involve porous and pervious concrete, porous or rubberized asphalt, permeable interlocking concrete, etc. Modern permeable pavement technologies presenting a high performance involve: the use of water holding fillers made of steel by products as an additive, the addition of fine blast furnace powder in water retentive asphaltic pavements, the use of bottom ash and peat moss as additives in pervious concrete, the use of fine texture pervious mortar as an additive to pervious concrete, the use of fly ash with narrow particle distributions and the use of industrial wastes in ceramic tiles (Santamouris 2013).

c) By increasing the apparent thermal capacity of the pavements. This is mainly achieved through the use of phase change materials integrated in the mass of the paving surfaces. PCM materials permit to achieve a lower surface temperature during the day time and thus decrease the sensible heat released to the atmosphere.

d) By using mechanical systems in the mass of the pavements like tubes where water is circulated, that dissipate the excess heat of the concrete or asphalt and contribute to decrease their surface temperature.

e) By providing efficient shading of the paved surfaces to decrease the absorbed solar radiation.

All above technologies are widely used in real scale projects and most show a very high potential to decrease the surface of pavements, decrease the sensible heat released to the atmosphere and mitigate the impact of UHI in cities. Specific information of the existing applications is given by Santamouris (2013). 


\subsection{Greening the urban environment, the impact of trees in the city}

Urban greenery can bring about benefits to the microclimate through processes of shading, evapotranspiration, regulation of the air movement and heat exchange (Dimoudi, Nikolopoulou 2003). Numerous studies have highlighted the significance of urban parks and also of the strategic plant placement in landscape design (GómezMuñoz et al. 2010). Urban parks contribute highly to decrease ambient temperatures in the adjacent urban zones while help to mask urban noise, filter urban pollutants, prevent erosion and stabilize the soil and also provide relaxation to the visitors (Zoulia et al. 2009).

Parks offer an important mitigation potential in cities. The exact contribution on the climate quality of a city depends on complex regional and local factors like the size and structure of the park, the local weather conditions, the type of plants used, the watering frequency, the thermal balance around the park, and the thermal characteristics of the whole city (Skoulika et al. 2014). Most of the existing studies aiming to identify the proper size of parks concluded that the larger the park the higher its mitigation potential is (Bowler et al. 2010). However, experimental studies investigating the cooling potential of small and medium size urban parks concluded that they have a very significant impact on the local climate (Watkins et al. 2002).

Recent reviews of the existing experimental studies concerning the mitigation potential of urban parks concluded that parks are in average $0.94 \mathrm{~K}$ cooler than the urban areas (Bowler et al. 2010), while the daytime cool island intensity of parks varies between $0.3 \mathrm{~K}$ to $7 \mathrm{~K}$ (Skoulika et al. 2014). The temperature difference between the park and the adjacent urban areas creates a significant pressure difference that permit the transfer of cool air from the park to the urban areas. The magnitude of the affected urban zone depends highly on the size of the park and, according to Spronken-Smith (1994), it is limited to a distance around the park width. Other experimental studies reported that the length of the affected urban area may be extended between 200 to $1000 \mathrm{~m}$ from the park boundaries as a function of the wind direction and speed and the thermal balance of the surrounding areas. In fact, an almost negligible influence of the urban parks is found in urban zones with a high anthropogenic heat release (Zoulia et al. 2009).

With the benefits of greenery widely acknowledged, the next challenge is to translate this knowledge into industry practice. While there are existing frameworks to objectify landscape planning processes such as maintainability and irrigation, methodologies for assessing landscape proposals in terms of plant cooling potential have yet to be exhaustively formalized. The problem of visualizing the thermal impact of any landscape design is exacerbated by the inclusion of alternate forms of vegetation such as vertical and rooftop greenery.
Recent developments in modelling the outdoor thermal environment have enabled scientists to understand the impact of vegetation in landscape planning. Climatic maps are able to serve as visualisation aid from micro to macro level. Through the Geographical Information Systems (GIS) platform, multiple layers of spatial information can be analysed simultaneously and the use of climatic mapping has become a prominent feature in studies of the outdoor climate. In particular, there has been extensive usage of GIS for the mapping of green spaces providing opportunities to propose landscape solutions via GIS mapping techniques.

Objective plant selection and placement are important factors in landscape planning. Introduction of thermal simulation in the studies has highlighted the importance of context and locality. Adjacent buildings can affect solar exposure significantly, thereby influencing the plant placement process, dispelling the common myth that plants can improve the environment by cooling temperature indiscriminately. Landscape planning needs to more effectively realize the cooling effects of greenery as an urban heat mitigation technique and to optimize urban greenery as an ecosystem resource.

\subsection{Actual development of green roof technologies}

Green roofs are building structures covered by a vegetation layer. Green roof synonyms are: eco roof, living roof, roof garden as also indicated in current literature. The vegetation layer can also be applied in building walls. In this case the technology is defined as green façade and it is out of the scope of the present review.

While cool roof is a simple building solution in terms of installation for new and existing buildings, the green roof is a more complex technology consisting of several layers which, in the more general case, include from down to top: the structural substrate of the roof, the waterproofing membrane, the root barrier, the thermal insulation layers (not always present or, in some cases, included in the structural substrate of the roof), the drainage, aeration and retention layer, the filter fabric, avoiding small particle to clog the drainage, the growing medium (soil), including the irrigation system if needed, and the vegetation layer.

Green roofs are classified as extensive and intensive: The former technology is characterised by a thin growing medium layer with low level planting, as: sedum, brushes or lawn. This solution requires no maintenance in general and limited water needs. Intensive green roofs are gardens with a thicker growing medium, so that rooting plants such as shrubs and trees can grow and live; they are characterised by higher water needs and adequate structural substrates. A further class, the semi-intensive green roof, is also used in some cases (Theodosiou 2009).

Green roofs were known and used since ancient times, even if the technology started gaining popularity in the second half of the $20^{\text {th }}$ century due to the increase 
of thermal insulation provided by the systems. In addition to this function, green roofs became a key technology for sustainable buildings in recent years. Benefits provided by green roofs include: storm water management, water run-off management, improved urban air quality, extension of roof life, enhanced architectural quality and biodiversity.

In the past years, green roofs were pointed as key technology to reduce the outdoor air temperature, thus mitigating the urban heat island phenomenon, which finds in the lack of green areas in the urban environments one of the most important grounds (Gaitani et al. 2007; Santamouris 2014b). The mitigation performances and potentialities of green roofs depend on several (micro) climatic parameters as: air temperature, solar radiation, ambient humidity, precipitation and wind speed. They set the boundary conditions for the green roof system thermal response, whose most important parameters are:

- Thermo-physical properties of each layer of the roofing system including the growing medium (density, thermal capacity, thermal conductivity, thickness);

- Water content of the growing medium, provided by the irrigation systems and precipitations;

- Vegetation layer properties (leaves emissivity and solar reflectance, stoma resistance, leaf area index (LAI), driving the released latent heat by evapotranspiration.

While a number of studies demonstrated the potentialities of green roof in improving the thermal and energy performances of the built environment, either during the heating and cooling season (Zinzi, Agnoli 2012), the same does not apply for investigations dedicated to the estimation of the urban heat island mitigation. For the latter case two approaches are basically implemented: assessment of urban heat island mitigation through mesoscale simulation analyses and assessment of the latent and sensible heat flux from green roofs.

The mesoscale study carried out in Smith and Roeber (2011) estimated the mitigation potential in the city of Chicago, U.S., a city deeply involved in mitigation actions where $50,000 \mathrm{~m}^{2}$ of green roof were installed in 2008. The study was carried out assuming the extensive green roof performance equivalent to that of a conventional roof with a 0.8 solar reflectance, thus neglecting the latent phenomena. The results showed a $2-3 \mathrm{~K}$ reduction of the air temperature in the $7.00-11.00 \mathrm{pm}$ hours as a consequence of the green roofs replacing the existing ones. A similar study was carried out by Rosenzweig et al. (2006) for New York City, U.S. The impact of the extensive green roof application results in an air temperature reduction of $0.37-0.86 \mathrm{~K}$ during peak time and $0.3-0.55 \mathrm{~K}$ as daily average.

Measurements of the air temperature above green and conventional roofs were carried out in Singapore and Taipei (Wong et al. 2003; Sun et al. 2012). Main findings are that green roofs are more effective when the roof height is below $10 \mathrm{~m}$ with respect to the street level and that benefits decrease with the distance from the roofs.
Analyses of the latent heat flux magnitude were carried out at numerical, theoretical and experimental level and are reviewed in Santamouris (2014b). It was found that such fluxes vary in the $100-600 \mathrm{~W} / \mathrm{m}^{2}$ as a function of site, building and green roof characteristics. The latent heat release under a $900 \mathrm{~W} / \mathrm{m}^{2}$ solar irradiation varies between 300 and $400 \mathrm{~W} / \mathrm{m}^{2}$, the value decreases to 110 and $230 \mathrm{~W} / \mathrm{m}^{2}$ for respectively dry and wet green roof. Climatic dependent analyses were also performed in Kolokotsa et al. (2013a). In the island of Crete, Greece, it was found that the maximum sensible heat flux associated to a conventional roof is $157 \mathrm{~W} / \mathrm{m}^{2}$, the value decrease to $104,70,33$ and $21 \mathrm{~W} / \mathrm{m}^{2}$ for respectively $0.5,1,2$ and 3 leaf area index. The exercise was also carried for London, United Kingdom, with different results respect to a Mediterranean climate: the maximum sensible heat flux associated to a conventional roof is $87 \mathrm{~W} / \mathrm{m}^{2}$, the value decrease to $56,37,17$ and $10 \mathrm{~W} / \mathrm{m}^{2}$ for respectively 0.5 , 1,2 and 3 leaf area index. On a seasonal basis, the effect of a non-irrigated cool roof is the reduction of the sensible heat flux by $58 \%$ in Crete (from 176 to $73 \mathrm{~W} / \mathrm{m}^{2}$ ) and by $83 \%$ in London (from 119 to $20 \mathrm{~W} / \mathrm{m}^{2}$ ).

Comparison of the performance of reflective against the green roofs performed by Santamouris (2014b) concluded that green roofs may present a similar or higher performance when the latent heat exceeds $400 \mathrm{~W} / \mathrm{m}^{2}$. This is achieved when the green roof system is very well irrigated and the LAI is higher than 4.

Actual studies show the potentiality of the green roof technology in reducing the sensible and latent heat released to the urban environment and, as a consequence, mitigating the urban heat island phenomenon. However, the topic still needs to be investigated to predict with accuracy the urban temperature reduction as a function of: climatic conditions, green roof characteristics, city footprint covered with green roofs, distance between the roof and the street level. Experimental, numerical and theoretical studies should cover these issues in the next year to fully exploit the potential technology and take advantage of the market penetration to reduce the installation prices and make the technology more cost effective.

\subsection{Other mitigation technologies}

To counterbalance the impact of heat island, several mitigation techniques have been designed, developed and tested in real projects with sufficient success. Apart from cool materials and greenery, the use of solar control as well as the dissipation of the excess heat in low temperature environmental heat sinks like the ground, the water and the ambient air have been also applied.

Shading of outdoor spaces is a fundamental and important technique for the improvement of the urban microclimate. Proper shading systems can contribute to a significant reduction of the radiative temperature improving simultaneously the thermal comfort conditions. The use of suitable permeable materials in open spaces can offer a significant reduction of both ambient and radiative temperature allowing the air to flow and move 
through them. Shading of the urban environment can be provided by shading devices and structures, like tents, pergolas, canopies, etc. Shaded urban surfaces receive smaller amounts of solar radiation, thus having lower temperatures. This results in lower ambient temperatures in open spaces. The shading efficiency in improving the urban microclimate has already been tested by various researchers. Shashua-Bar et al. (2011) compared an exposed courtyard, which a maximum air temperature of $34{ }^{\circ} \mathrm{C}$ in mid-afternoon with a similar courtyard treated a fabric shading mesh. The air temperature was decreased by at least $1.5{ }^{\circ} \mathrm{C}$. Another study performed in the outdoor conditions of a university campus in central Taiwan (Hwang et al. 2011) an important factor in urban environments, affects thermal environments and longterm thermal comfort, this study conducted several field experiments to analyze the outdoor thermal conditions on urban streets in central Taiwan. The RayMan model was utilized for predicting long-term thermal comfort using meteorological data for a 10 -year period. Analytical results indicate that slightly shaded areas typically have highly frequent hot conditions during summer, particularly at noon. However, highly shaded locations generally have a low physiologically equivalent temperature (PET showed that the barely shaded (high SVFs) locations were uncomfortable in summer and highly shaded locations (low SVFs) were uncomfortable in winter. For outdoor space design, multiple shading types and different shading levels were proposed.

Concerning heat sinks, it is well known that the ground temperature at a depth of about 2.5 to $3 \mathrm{~m}$ remains fairly constant and low around the year (Zoras 2009). Taking advantage of the ground temperature is achieved through ground to air heat exchangers, meaning tubes that are buried in the earth. The air enters the tubes; it is circulated underground and exits the tube having a lower temperature. The designation of this system varies, as it could be referred to as "earth tubes" or as "groundcoupled air heat exchangers". The idea of using ground cooling to dissipate the excess heat from the outdoor area to the ground is applied by various researchers. For example, earth to air heat exchangers have been applied in the Marousi area of Athens Greece by Santamouris et al. (2012). The combined effect of ground cooling with all the other rehabilitation techniques has resulted to $3.4 \mathrm{~K}$ reduction of air temperature under peak summer climatic conditions. At the same time, an important decrease of the surface temperature was calculated, resulting in a very significant improvement of thermal comfort conditions. Moreover, Fintikakis et al. (2011) through simulations and on field measurements evaluated the microclimatic modifications that were applied in the historic centre of Tirana, in Albania. The mitigation techniques included apart from cool materials, green spaces, the use of solar control and earth to air heat exchangers. The researchers found that the maximum temperature drop due to all the applied techniques was $3{ }^{\circ} \mathrm{C}$, while the maxi- mum contribution of the earth to air heat exchangers was found to be close to $0.7^{\circ} \mathrm{C}$ (Fintikakis et al. 2011).

Moreover, water shows several advantages as a natural cooling technique in order to cool the urban environment due to its thermal and optical properties. The high specific heat of water is of an order of about four times the value of most urban materials, and as a consequence the thermal inertia of water is then four times higher. The effect of the thermal inertia is double: to delay and buffer the maximum temperature. The evaporation process of water requires a high amount of latent heat. When a drop of water is evaporated, this energy comes from the surrounding air and water, resulting in this way in a cooler air and water. The low reflectivity of water causes a low solar reflection to other surfaces in the surroundings, avoiding in this way their warming up (Littlefair et al. 2000).

Water bodies have been extensively used to regulate the urban temperature (Demuzere, Coutts 2012) due to the contribution of the enhanced evaporation during daytime. For example significant reductions of air temperatures around urban lakes and rivers have been reported by various researchers. Hathway and Sharples (2011) found significant reductions of urban air temperatures due to river proximity. Also, they state that the cooling power is strongest in early spring and already reduces in June. Moreover, in the framework of LIFE "ECO-Valle Mediterranean Verandahways" project, the Ecosistema Urbano Office Architects have designed and built a bioclimatic boulevard at the New Expansion of Vallecas (Madrid, Spain) (Soutullo et al. 2011). In this avenue a temporary installation of evaporating towers provide a cooling effect to the pedestrians. The average temperature decrease due to the evaporative cooling at the pedestrians' height $(1 \mathrm{~m})$ is almost $3.5^{\circ} \mathrm{C}$ with an average saturated cooling efficiency of about $32 \%$.

Each of the above mentioned mitigation techniques, have positive results in reducing the heat island effect when applied in the urban environment. However, the combination of some or all of the strategies, depending on the specific site and weather patterns, will have multiple benefits.

\section{Conclusions and future prospects of mitigation technologies}

Urban heat island is the more documented phenomenon of climatic change causing important energy and environmental problems to cities. To counterbalance the impact of the phenomenon, important research has been carried out to develop proper mitigation technologies able to decrease ambient and surface temperatures in cities. Mitigation of urban heat islands leads to energy and energy expenditure savings, improves urban air quality and ambient conditions, and help to counter global warming. Many implementation technologies exist and are used; in parallel, many scientific and administrative activities support the implementation of UHI mitigation technologies. 
For example, the "100 Cool Cities" program has been developed to encourage cities to commit in developing implementation program, share their experience with other cities, and develop mechanisms for common implementation programs. Standards have been developed to measure solar reflectance of roofing and paving materials. These standards are used by labelling organizations such as Cool Roofs Rating Council (CRRC 2015) and European Cool Roof Council (ECRC 2015) to develop programs and label materials. An accelerated aging standard has been developed to help the manufacturers in estimating the aged optical performance of newly developed materials. The building energy codes and standards have been updated to include the solar reflectance of roofing materials in building minimum specific requirements. These standards are very effective in marketing and deployment of cool roofs to save energy. To promote the cool cities program throughout the world, a non-profit organization, Global Cool Cities Alliance (GCCA 2015), has been founded. GCCA is currently active in helping many countries in the world to implement cool roofs and cool pavement in their cities.

Cool roofs and cool pavements are considered generic technologies; yet taken the availability of local materials and implementation practices; customized programs need to be developed in each city. Cities should embark on programs to:

- Perform detailed analysis to quantify energy and air quality effects of the measures;

- Develop - and periodically update - detailed land use/land cover database;

- Develop customized implementation programs (roofs, pavements, trees);

- Coordinate work with national governments and regional agencies;

- Develop regional energy codes, standards, guidelines;

- Develop a feedback system in order to improve customized programs;

- Develop demonstration projects in order to improve the awareness of the public.

Finally, the research community should focus to two major topics: 1) Develop materials based on local market and available resources and 2) Working with the local policy makers to develop effective implementation programs.

\section{References}

Akbari, H. 1992. Cooling our communities: a guidebook on tree planting and light coloured surfaces. Lawrence Berkeley National Laboratory, Heat Island Group LBNL, USA. 245 p.

Akbari, H.; Konopacki, S.; Pomerantz, M. 1999. Cooling energy savings potential of reflective roofs for residential and commercial buildings in the United States, Energy 24(5): 391-407.

http://dx.doi.org/10.1016/S0360-5442(98)00105-4
Akbari, H.; Rose, L. S. 2001. Characterizing the fabric of the urban environment: a case study of metropolitan Chicago, Illinois. Lawrence Berkeley National Laboratory. LBNL Report No. LBNL-49275, Berkeley, CA.

Akbari, H.; Matthews, H. D.; Seto, D. 2012. The long-term effect of increasing the albedo of urban areas, Environmental Research Letters 7(2), 024004. http://dx.doi.org/10.1088/1748-9326/7/2/024004

Akbari, H.; Matthews, H. D. 2012. Global cooling updates: reflective roofs and pavements, Energy and Buildings 55: 2-6. http://dx.doi.org/10.1016/j.enbuild.2012.02.055

Akbari, H.; Touchaei, A. G. 2014. Modeling and labeling heterogeneous directional reflective roofing materials, Solar Energy Materials and Solar Cells 124: 192-210. http://dx.doi.org/10.1016/j.solmat.2014.01.036

Asaeda, T.; Thanh, C. V.; Wake, A. 1996. Heat storage of pavement and its effect on the lower atmosphere, Atmospheric Environment 30(3): 413-427. http://dx.doi.org/10.1016/1352-2310(94)00140-5

Baccini, M.; Kosatsky, T.; Analitis, H. R.; Anderson, M.; D’Ovidio, M.; Menne, B.; Michelozzi, P.; Biggeri, A. 2011. Impact of heat on mortality in 15 European cities: attributable deaths under different weather scenarios, Journal of Epidemiology and Community Health 65: 6470. http://dx.doi.org/10.1136/jech.2008.085639

Bowler, D. E.; Buyung-Ali, L.; Knight, T. M.; Pullin, A. S. 2010. Urban greening to cool towns and cities: a systematic review of the empirical evidence, Landscape and Urban Planning 97(3): 147-155. http://dx.doi.org/10.1016/j.landurbplan.2010.05.006

Cool Roofs Rating Council (CRRC). 2015 [online], [cited 10 September 2015]. Available from Internet: http://coolroofs.org/

Demuzere, M.; Coutts, A. 2012. Application of urban climate modelling for assessment of WSUD, in WSUD 2012 - $7^{\text {th }}$ International Conference on Water Sensitive Urban Design: Building the Water Sensitive Community, 2012, Barton, A.C.T.: Engineers Australia, 762-780.

Diamanti, M. V.; Paolini, R.; Zinzi, M.; Ormellese, M.; Fiori, M.; Pedeferri, M. P. 2013. Self-cleaning ability and cooling effect of $\mathrm{TiO}_{2}$-containing mortars, in Technical Proc. of the NSTI-Nanotech 2013 - 2013 NSTI Nanotechnology Conference and Expo, 12-16 May 2013, Washington, DC, USA, 3: 716-719.

Dimoudi, A.; Nikolopoulou, M. 2003. Vegetation in the urban environment: microclimatic analysis and benefits, Energy and Buildings 35(1): 69-76. http://dx.doi.org/10.1016/S0378-7788(02)00081-6

European Environment Agency (EEA). 2006. Environment and human health. Joint EEA-JRC report No. 5/2013.

European Environment Agency (EEA). 2010. European environment state and outlook 2010: urban environment. SOER 2010 Report. 228 p.

European Environment Agency (EEA). 2012. Climate change, impacts and vulnerability in Europe. An indicator-based report. Report No. 12/2012. 300 p.

European Environment Agency (EEA). 2013. Adaptation in Europe - Addressing risks and opportunities from climate change in the context of socioeconomic developments. Report No. 3/2013. $136 \mathrm{p}$.

European Environment Agency (EEA). 2015. SOER 2015 - the European environment - state and outlook. A comprehensive assessment of the European environment's state, trends and prospects, in a global context. SOER $2015 \mathrm{Re}-$ port. $212 \mathrm{p}$.

European Cool Roof Council (ECRC). 2015 [online], [cited 10 September 2015]. Available from Internet: http://coolroofcouncil.eu/ 
Ferrari, C.; Libbra, A.; Muscio, A.; Siligardi, C. 2013. Design of ceramic tiles with high solar reflectance through the development of a functional engobe, Ceramics International 39(8): 9583-9590. http://dx.doi.org/10.1016/j.ceramint.2013.05.077

Fintikakis, N.; Gaitani, N.; Santamouris, M.; Assimakopoulos, M.; Assimakopoulos, D. N.; Fintikaki, M.; Albanis, G.; Papadimitriou, K.; Chryssochoides, E.; Katopodi, K.; Doumas, P. 2011. Bioclimatic design of open public spaces in the historic centre of Tirana, Albania, Sustainable Cities and Society 1(1): 54-62. http://dx.doi.org/10.1016/j.scs.2010.12.001

Gaitani, N.; Michalakakou, G.; Santamouris, M. 2007. On the use of bioclimatic architecture principles in order to improve thermal comfort conditions in outdoor spaces, Building and Environment 42(1): 317-324. http://dx.doi.org/10.1016/j.buildenv.2005.08.018

Gartland, L. 2008. Heat islands: understanding and mitigating heat in urban areas. Earthscan, UK. 58 p.

Global Cool Cities Alliance (GCCA). 2015 [online], [cited 10 September 2015]. Available from Internet: http://www.globalcoolcities.org/

Gómez-Muñoz, V. M.; Porta-Gándara, M.; Fernández, J. 2010. Effect of tree shades in urban planning in hot-arid climatic regions, Landscape and urban planning 94(3): 149-157. http://dx.doi.org/10.1016/j.landurbplan.2009.09.002

Grimmond, S. 2011. Climate in cities, in I. Douglas, D. Goode, M. Houck, R. Wang. The Routledge handbook of urban ecology. Part 10. Routledge, UK.

Hathway, A.; Sharples, S. 2011. Urban river microclimates, in PLEA 2011 - Architecture and Sustainable Development, Conference Proceedings of the $27^{\text {th }}$ International Conference on Passive and Low Energy Architecture, 13-15 July 2011, Louvain-la-Neuve, Belgium, 183-187.

Hosseini, M.; Akbari, H. 2014. Heating energy penalties of cool roofs: the effect of snow accumulation on roofs, Advances in Building Energy Research 8(1): 1-13. http://dx.doi.org/10.1080/17512549.2014.890541

Hwang, R. L.; Lin, T. P.; Matzarakis, A. 2011. Seasonal effects of urban street shading on long-term outdoor thermal comfort, Building and Environment 46(4): 863-870. http://dx.doi.org/10.1016/j.buildenv.2010.10.017

International Council for Local Environmental Initiatives (ICLEI). 2013 [online], [cited 10 September 2015]. Available from Internet: http://resilientcities.iclei.org/ resilient-cities-hub-site/about-the-global-forum/resilientcities-2013/

Intergovernmental Panel on Climate Change (IPCC). 2014. Summary for policymakers, in Climate Change 2014: Impacts, Adaptation, and Vulnerability. Contribution of Working Group II to the Fifth Assessment Report of the Intergovernmental Panel on Climate Change. Cambridge, UK: Cambridge University Press. 18 p.

Kamal-Chaoui, L.; Alexis, R. (Eds.). 2009. Competitive cities and climate change. OECD Regional Development Working Paper No. 2. 172 p.

http://dx.doi.org/10.1787/218830433146

Karlessi, T.; Santamouris, M.; Apostolakis, K.; Synnefa, A.; Livada, I. 2009. Development and testing of thermochromic coatings for buildings and urban structures, Solar Energy 83(4): 538-551.

http://dx.doi.org/10.1016/j.solener.2008.10.005

Karlessi, T.; Santamouris, M.; Synnefa, A.; Assimakopoulos, D.; Didaskalopoulos, P.; Apostolakis, K. 2011. Development and testing of PCM doped cool coloured coatings to mitigate urban heat island and cool buildings, Building and Environment 46(3): 570-576.

http://dx.doi.org/10.1016/j.buildenv.2010.09.003
Karlessi, T.; Santamouris, M. 2013. Improving the performance of thermochromic coatings with the use of UV and optical filters tested under accelerated aging conditions, International Journal of Low-Carbon Technologies 10(1): 45-61. http://dx.doi.org/10.1093/ijlct/ctt027

Kolokotroni, M.; Davies, M.; Croxford, B.; Bhuyan, S.; Mavrogianni, A. 2010. A validated methodology for the prediction of heating and cooling energy demand for buildings within the urban heat island: case study of London, Solar Energy 84(12): 2246-2255.

http://dx.doi.org/10.1016/j.solener.2010.08.002

Kolokotsa, D.; Santamouris, M. 2015. Review of the indoor environmental quality and energy consumption studies for low income households in Europe, Science of the Total Environment 536: 316-330.

http://dx.doi.org/10.1016/j.scitotenv.2015.07.073

Kolokotsa, D.; Santamouris, M.; Akbari, H. 2013a. Advances in the development of cool materials for the built environment. Bentham eBooks. 385 p.

Kolokotsa, D.; Santamouris, M.; Zerefos, S. 2013b. Green and cool roofs' urban heat island mitigation potential in European climates for office buildings under free floating conditions, Solar Energy 95: 118-130.

http://dx.doi.org/10.1016/j.solener.2013.06.001

Levinson, R.; Berdahl, P.; Akbari, H. 2005a. Spectral solar optical properties of pigments - part I: model for deriving scattering and absorption coefficients from transmittance and reflectance measurements, Solar Energy Materials and Solar Cells 89(4): 319-349.

http://dx.doi.org/10.1016/j.solmat.2004.11.012

Levinson, R.; Berdahl, P.; Akbari, H. 2005b. Spectral solar optical properties of pigments - part II: survey of common colorants, Solar Energy Materials and Solar Cells 89(4): 351-389. http://dx.doi.org/10.1016/j.solmat.2004.11.013

Levinson, R.; Akbari, H.; Konopacki, S.; Bretz, S. 2005c. Inclusion of cool roofs in nonresidential Title 24 prescriptive requirements, Energy Policy 33(2): 151-170. http://dx.doi.org/10.1016/S0301-4215(03)00206-4

Levinson, R.; Berdahl, P.; Akbari, H.; Miller, W.; Joedicke, I.; Reilly, J.; Suzuki, Y.; Vondran, M. 2007. Methods of creating solar-reflective non white surfaces and their application to residential roofing materials, Solar Energy Materials and Solar Cells 91(4): 304-314. http://dx.doi.org/10.1016/j.solmat.2006.06.062

Littlefair, P. J.; Santamouris, M.; Alvarez, S.; Dupagne, A.; Hall, D.; Teller, J.; Coronel, J. F.; Papanikolaou, N. 2000. Environmental site layout planning: solar access, microclimate and passive cooling in urban areas. London: Building Research Establishment (BRE). 161 p.

Mastrapostoli, E.; Karlessi, T.; Pantazaras, A.; Kolokotsa, D.; Gobakis, K.; Santamouris, M. 2014. On the cooling potential of cool roofs in cold climates: use of cool fluorocarbon coatings to enhance the optical properties and the energy performance of industrial buildings, Energy and Buildings 69: 417-425. http://dx.doi.org/10.1016/j.enbuild.2013.10.024

Mavrogianni, A.; Davies, M.; Batty, M.; Belcher, S. E.; Bohnenstengel, S. I.; Carruthers, D.; Chalabi, Z.; Croxford, B.; Demanuele, C.; Evans, S.; Giridharan, R.; Hacker, J. N.; Hamilton, I.; Hogg, C.; Hunt, J.; Kolokotroni, M.; Martin, C.; Milner, J.; Rajapaksha, I.; Ridley, I.; Steadman, J. P.; Stocker, J.; Wilkinson, P.; Ye, Z. 2011. The comfort, energy and health implications of London's urban heat island, Building Services Engineering Research \& Technology 32(1): 35-52. http://dx.doi.org/10.1177/0143624410394530

Meehl, G.; Tebaldi, C. 2004. More intense, more frequent, and longer lasting heat waves in the $21^{\text {st }}$ century, Science 305 : 994-997. http://dx.doi.org/10.1126/science.1098704 
Pantavou, K.; Theoharatos, G.; Mavrakis, A.; Santamouris, M. 2011. Evaluating thermal comfort conditions and health responses during an extremely hot summer in Athens, Building and Environment 46(2): 339-344. http://dx.doi.org/10.1016/j.buildenv.2010.07.026

Pisello, A. L.; Santamouris, M.; Cotana, F. 2013. Active cool roof effect: Impact of cool roofs on cooling system efficiency, Advances in Building Energy Research 7(2): 209221. http://dx.doi.org/10.1080/17512549.2013.865560

Pisello, A. L.; Cotana, F. 2014. The thermal effect of an innovative cool roof on residential buildings in Italy: results from two years of continuous monitoring, Energy and Buildings 69: $154-164$. http://dx.doi.org/10.1016/j.enbuild.2013.10.031

Plan Batiment Grenelle. 2009 [online], [cited 10 September 2015]. Available from Internet: www.plan-batiment.legrenelle-environnement.fr

Qin, P.; Song, J.; Qu, J.; Xue, X.; Zhang, W.; Song, Z.; Shi, Y.; Jiang, L.; Li, J.; Zhang, T. 2014. The methods for creating building energy efficient cool black coatings, Energy and Buildings 84: 308-315. http://dx.doi.org/10.1016/j.enbuild.2014.08.022

Rose, L. S.; Akbari, H.; Taha, H. 2003. Characterizing the fabric of the urban environment: a case study of greater Houston, Texas. Berkeley, CA: Lawrence Berkeley National Laboratory. Paper No. LBNL-51448.

Rosenfeld, A. H.; Akbari, H.; Bretz, S.; Fishman, B. L.; Kurn, D. M.; Sailor, D.; Taha, H. 1995. Mitigation of urban heat islands: materials, utility programs, updates, Energy and Buildings 22(3): 255-265. http://dx.doi.org/10.1016/0378-7788(95)00927-P

Rossi, F.; Pisello, A. L.; Nicolini, A.; Filipponi, M.; Palombo, M. 2014. Analysis of retro-reflective surfaces for urban heat island mitigation: a new analytical model, Applied Energy 114: 621-631.

Rossi, F.; Castellani, B.; Presciutti, A.; Morini, E.; Filipponi, M.; Nicolini, A.; Santamouris, M. 2015. Retroreflective façades for urban heat island mitigation: Experimental investigation and energy evaluations, Applied Energy 145: 8-20. http://dx.doi.org/10.1016/j.apenergy.2013.10.038

Rosenzweig, C.; Solecki, W.; Parshall, L.; Gaffin, S.; Lynn, B.; Goldberg, R.; Cox, J.; Hodges, S. 2006. Mitigating New York city's heat island with urban forestry, living roofs, and light surfaces. New York City Regional Heat Island Initiative. The New York State Energy Research and Development Authority, Albany, NY. 4 p.

Sakka, A.; Santamouris, M.; Livada, I.; Nicol, F.; Wilson, M. 2012. On the thermal performance of low income housing during heat waves, Energy and Buildings 49: 69-77. http://dx.doi.org/10.1016/j.enbuild.2012.01.023

Santamouris, M. 2013. Using cool pavements as a mitigation strategy to fight urban heat island - a review of the actual developments, Renewable and Sustainable Energy Reviews 26: 224-240. http://dx.doi.org/10.1016/j.rser.2013.05.047

Santamouris, M. 2014a. On the energy impact of urban heat island and global warming on buildings, Energy and Buildings 82: 100-113.

http://dx.doi.org/10.1016/j.enbuild.2014.07.022

Santamouris, M. 2014b. Cooling the cities - a review of reflective and green roof mitigation technologies to fight heat island and improve comfort in urban environments, Solar Energy 103: 682-703.

http://dx.doi.org/10.1016/j.solener.2012.07.003

Santamouris, M. 2015a. Analyzing the heat island magnitude and characteristics in one hundred Asian and Australian cities and regions, Science of the Total Environment 512513: 582-598.

http://dx.doi.org/10.1016/j.scitotenv.2015.01.060
Santamouris, M. 2015b. Regulating the damaged thermostat of the cities - status, impacts and mitigation strategies, Energy and Buildings 91: 43-56. http://dx.doi.org/10.1016/j.enbuild.2015.01.027

Santamouris, M.; Papanikolaou, N.; Livada, I.; Koronakis, I.; Georgakis, C.; Argiriou, A.; Assimakopoulos, D. N. 2001. On the impact of urban climate on the energy consumption of buildings, Solar Energy 70(3): 201-216. http://dx.doi.org/10.1016/S0038-092X(00)00095-5

Santamouris, M.; Synnefa, A.; Kolokotsa, D.; Dimitriou, V.; Apostolakis, K. 2008. Passive cooling of the built environment - use of innovative reflective materials to fight heat island and decrease cooling needs, International Journal of Low Carbon Technologies 3(2): 71-82. http://dx.doi.org/10.1093/ijlct/3.2.71

Santamouris, M.; Synnefa, A.; Karlessi, T. 2011. Using advanced cool materials in the urban built environment to mitigate heat islands and improve thermal comfort conditions, Solar Energy 85: 3085-3102. http://dx.doi.org/10.1016/j.solener.2010.12.023

Santamouris, M.; Xirafi, F.; Gaitani, N.; Spanou, A.; Saliari, M.; Vassilakopoulou, K. 2012. Improving the microclimate in a dense urban area using experimental and theoretical techniques - the case of Marousi, Athens, International Journal of Ventilation 11(1): 1-16.

Santamouris, M.; Alevizos, S.; Aslanoglou, L.; Mantzios, D.; Milonas, P.; Sarelli, I.; Karatasou, S.; Cartalis, C.; Paravantis, J. A. 2014. Freezing the poor - indoor environmental quality in low and very low income households during the winter period in Athens, Energy and Buildings 70: 61-70. http://dx.doi.org/10.1016/j.enbuild.2013.11.074

Santamouris, M.; Cartalis, C.; Synnefa, A.; Kolokotsa, D. 2015a. On the impact of urban heat island and global warming on the power demand and electricity consumption of buildings - a review, Energy and Buildings 98: 119-124. http://dx.doi.org/10.1016/j.enbuild.2014.09.052

Santamouris, M.; Cartalis, C.; Synnefa, A. 2015b. Local urban warming, possible impacts and a resilience plan to climate change for the historical center of Athens, Greece, Sustainable Cities and Society 19: 281-291. http://dx.doi.org/10.1016/j.scs.2015.02.001

Shashua-Bar, L.; Pearlmutter, D.; Erell, E. 2011. The influence of trees and grass on outdoor thermal comfort in a hot-arid environment, International Journal of Climatology 31: 1498-1506. http://dx.doi.org/10.1002/joc.2177

Skoulika, F.; Santamouris, M.; Kolokotsa, D.; Boemi, D. 2014. On the thermal characteristics and the mitigation potential of a medium size urban park in Athens, Greece, Landscape and Urban Planning 123: 73-86. http://dx.doi.org/10.1016/j.landurbplan.2013.11.002

Sleiman, M.; Ban-Weiss, G.; Gilbert, H. E.; François, D.; Berdahl, P.; Kirchstetter, T. W.; Destaillats, H.; Levinson, R. 2011. Soiling of building envelope surfaces and its effect on solar reflectance - Part I: analysis of roofing product databases, Solar Energy Materials and Solar Cells 95(12): 3385-3399.

http://dx.doi.org/10.1016/j.solmat.2011.08.002

Sleiman, M.; Kirchstetter, T. W.; Berdahl, P.; Gilbert, H. E.; Quelen, S.; Marlot, L.; Preble, C. V.; Chen, S.; Montalbano, A.; Rosseler, O.; Akbari, H.; Levinson, R.; Destaillats, H. 2014. Soiling of building envelope surfaces and its effect on solar reflectance - part II: development of an accelerated aging method for roofing materials, Solar Energy Materials and Solar Cells 122: 271-281. http://dx.doi.org/10.1016/j.solmat.2013.11.028

Smith, K.; Roeber, P. 2011. Green roof mitigation potential for a proxy future climate scenario in Chicago, Illinois, Journal Applied Meteorology and Climatology 50: 507-522. http:// dx.doi.org/10.1175/2010JAMC2337.1 
Soutullo, S.; Olmedo, R.; Sánchez, M. N.; Heras, M. R. 2011. Thermal conditioning for urban outdoor spaces through the use of evaporative wind towers, Building and Environment 46(12): 2520-2528. http://dx.doi.org/10.1016/j.buildenv.2011.06.003

Spronken-Smith, R. A. 1994. Energetics and cooling in urban parks: PhD thesis. The University of British Columbia, Vancouver, Canada.

Stathopoulou, E.; Mihalakakou, G.; Santamouris, M.; Bagiorgas, H. 2008. On the impact of temperature on tropospheric ozone concentration levels in urban environments, Journal of Earth System Science 117(3): 227-236. http://dx.doi.org/10.1007/s12040-008-0027-9

Stone, B.; Hess, J. J.; Frumkin, H. 2010. Urban form and extreme heat events: are sprawling cities more vulnerable to climate change than compact cities?, Environmental Health Perspectives 118: 1425-1428. http://dx.doi.org/10.1289/ehp.0901879

Stone, B.; Vargo, J.; Habeeb, D. 2012. Managing climate change in cities: will climate action plans work?, Landscape and Urban Planning 107(3): 263-271. http://dx.doi.org/10.1016/j.landurbplan.2012.05.014

Sun, C.-Y.; Lee, K.-P.; Lin, T.-P.; Lee, S.-H. 2012. Vegetation as a material of roof and city to cool down the temperature, Advanced Materials Research 461: 552-556.

http://dx.doi.org/10.4028/www.scientific.net/AMR.461.552

Synnefa, A.; Santamouris, M.; Livada, I. 2006. A study of the thermal performance of reflective coatings for the urban environment, Solar Energy 80(8): 968-981. http://dx.doi.org/10.1016/j.solener.2005.08.005

Synnefa, A.; Santamouris, M.; Akbari, H. 2007a. Estimating the effect of using cool coatings on energy loads and thermal comfort in residential buildings in various climatic conditions, Energy and Buildings 39(11): 1167-1174. http://dx.doi.org/10.1016/j.enbuild.2007.01.004

Synnefa, A.; Santamouris, M.; Apostolakis, K. 2007b. On the development, optical properties and thermal performance of cool coloured coatings for the urban environment, Solar Energy 81(4): 488-497. http://dx.doi.org/10.1016/j.solener.2006.08.005

Synnefa, A.; Karlessi, T.; Gaitani, N.; Santamouris, M.; Assimakopoulos, D. N.; Papakatsikas, C. 2011. On the optical and thermal performance of cool coloured thin layer asphalt used to improve urban microclimate and reduce the energy consumption of buildings, Building and Environment 46(1): 38-44.

http://dx.doi.org/10.1016/j.buildenv.2010.06.014

Synnefa, A.; Santamouris, M. 2012. Advances on technical, policy and market aspects of cool roof technology in Europe: The Cool Roofs project, Energy and Buildings 55: 35-41. http://dx.doi.org/10.1016/j.enbuild.2011.11.051

Synnefa, A.; Saliari, M.; Santamouris, M. 2012. Experimental and numerical assessment of the impact of increased roof reflectance on a school building in Athens, Energy and Buildings 55: 7-15. http://dx.doi.org/10.1016/j.enbuild.2012.01.044

Taha, H.; Akbari, H.; Rosenfeld, A.; Huang, J. 1989. Residential cooling loads and the urban heat island-the effects of albedo, Building and Environment 23(4): 271-283. http://dx.doi.org/10.1016/0360-1323(88)90033-9
Taha, H. 2008. Meso-urban meteorological and photochemical modelling of heat island mitigation, Atmospheric Environment 42(38): 8795-8809. http://dx.doi.org/10.1016/j.atmosenv.2008.06.036

Takebayashi, H.; Moriyama, M. 2012. Relationships between the properties of an urban street canyon and its radiant environment: introduction of appropriate urban heat island mitigation technologies, Solar Energy 86(9): 2255-2262. http://dx.doi.org/10.1016/j.solener.2012.04.019

Theodosiou, T. 2009. Green roofs in buildings: thermal and environmental behaviour, Advances in Building Energy Research 3(1): 271-288. http://dx.doi.org/10.3763/aber.2009.0311

Tobias, A de Olalla, P. G.; Linares, C.; Bleda, M. J.; Cayla, J. A.; Diaz, J. 2010. Short-term effects of extreme hot summer temperatures on total daily mortality in Barcelona, Spain, International Journal of Biometeorology 54(2): 115-117. http://dx.doi.org/10.1007/s00484-009-0266-8

United Nations. 2014. World urbanization prospects: the 2014 revision, highlights. United Nations, Department of Economic and Social Affairs, Population Division, ST/ESA/ SER.A/352.

Watkins, R.; Palmer, J.; Kolokotroni, M.; Littlefair, P. 2002. The London heat island - surface and air temperature measurements in a park and street gorges, ASHRAE Transactions 108(1): 419-427.

World Health Organization (WHO). 2008. Protecting health in Europe from climate change. Geneva: World Health Organization. $54 \mathrm{p}$.

World Health Organization (WHO). 2011. Air quality and health. Fact sheet No 313. Geneva: World Health Organization.

Wilby, R. L. 2007. A review of climate change impacts on the built environment, Built Environment 33(14): 31-45. http://dx.doi.org/10.2148/benv.33.1.31

Wong, N. H.; Chen, Y.; Ong, C. L.; Sia, A. 2003. Investigation of thermal benefits of rooftop garden in the tropical environment, Building and Environment 38(4): 261-270. http://dx.doi.org/10.1016/S0360-1323(02)00066-5

Zheng, M.; Han, L.; Wang, F.; Mi, H.; Li, Y.; He, L. 2015. Comparison and analysis on heat reflective coating for asphalt pavement based on cooling effect and anti-skid performance, Construction and Building Materials 93: 11971205. http://dx.doi.org/10.1016/j.conbuildmat.2015.04.043

Zinzi, M.; Agnoli, S. 2012. Cool and green roofs: an energy and comfort comparison between passive cooling and mitigation urban heat island techniques for residential buildings in the Mediterranean region, Energy and Buildings 55: 66-76. http://dx.doi.org/10.1016/j.enbuild.2011.09.024

Zinzi, M. 2014. Characterisation and assessment of near infrared reflective paintings for building façade applications, Energy and Buildings, In Press. http://dx.doi.org/10.1016/j.enbuild.2015.05.048

Zoras, S. 2009. A review of building earth-contact heat transfer, Advances in Building Energy Research 3(1): 289-314. http://dx.doi.org/10.3763/aber.2009.0312

Zoulia, I.; Santamouris, M.; Dimoudi, A. 2009. Monitoring the effect of urban green areas on the heat island in Athens, Environmental Monitoring and Assessment 156(1-4): 275-292. http://dx.doi.org/10.1007/s10661-008-0483-3

Hashem AKBARI. He is a Professor at Concordia University (Montreal, Canada). Prior to joining the Concordia University he was the leader of the Heat Island Group, Senior Scientist, and principal investigator in the Environmental Energy Technologies Division at LBNL. He has obtained his PhD in engineering from the University of California, Berkeley. His research interest include: cool roofs and cool pavements, heat island reduction, effect of energy use on environment and climate, energy use and conservation in buildings; advanced energy technologies; utility energy forecasting; advanced utility-customer communication, computation, and control systems; energy-efficient environment; air pollution control; and environmental simulation and modeling. Dr Akbari is the author of more than 200 articles and coauthor of four books, and chief editor and editor of several scientific journals. 
Constantinos CARTALIS. He is Associate Professor of Environmental Physics at the University of Athens. He is also visiting professor at the graduate program of the Open University of Greece in the field of sustainable urban planning. He is elected member of the International Bureau of Education-UNESCO and national representative of the international environmental science education program GLOBE. He has acted as elected member of the Scientific Committee of the European Environment Agency. He has published 85 papers in international accredited journals.

Denia KOLOKOTSA. Dr, is currently an Assistant Professor at the School of Environmental Engineering of the Technical University of Crete, Greece. Her research interests include energy management for the built environment, energy efficiency and renewables. Moreover, she has developed expertise in the field of urban dynamics and environmental and ecological issues at the metropolitan and regional scale with emphasis on the urban heat island mitigation and adaptation strategies. She is the author of more than 100 papers published in high impact scientific journals and conference proceedings. She is the Editor-in-Chief of the Advances in Building Energy Research, Taylor and Francis as well as Editorial Board Member of Renewable Energy and Energy and Buildings Journal of Elsevier. Finally she has participated in more than 25 European and national projects and coordinated 3 EU (FP7 and Horizon) projects as well as 3 national projects.

Alberto MUSCIO. He is an Associate Professor in heat transfer and thermal-fluid sciences at the University of Modena and Reggio Emilia, Italy. His research is in the fields of energy efficiency and thermal comfort of buildings, renewable energy sources, development of materials and solutions for thermal insulation and control of solar gains, measurement of thermophysical properties. He is operations manager of the Energy Efficiency Laboratory at Modena, President of the Italian Association for Thermophysical Properties, member of the board of the European Cool Roof Council, leading scientist of the EU Project MAIN for dissemination of cool roofs and cool pavements.

Anna Laura PISELLO. PhD, Assistant professor at University of Perugia, Italy. Her research interests are focused on building physics, new smart and multifunctional materials for building thermal-energy efficiency, microclimate and mesoclimate phenomena analysis, eco-feedback processes. She is member of the editorial board of three international scientific journals, author of more than 40 publications in peer reviewed research journals, and winner of 4 international research awards in 2013-2014. She is member of Honors Center of Italian Universities for the Italy-USA scientific cooperation and of a UNESCO Chair. Dr Pisello was visiting scholar at Columbia University, Baruch College and Virginia Tech where she is actually co-advisor of a PhD student. Winner of 4 international research awards in 2013-2014.

Federico ROSSI. He is Associate Professor of Applied Physics at the University of Perugia. Since 1998, he held courses of Applied Physics and Energetics. He is PhD graduated on "Thermophysical properties of materials". He is author of more than 200 papers on the following fields: applied acoustics, applied thermodynamics and properties of materials, heat transmission and renewables. Cool material and building physics are his main on-going research topics.

Matheos SANTAMOURIS. He is Professor of Energy Physics at the University of Athens and visiting professor in six other international Universities. Editor in Chief of the Energy and Buildings Journal and Associate Editor or member of the editorial committee in 10 other journals. Editor and author of 13 international scientific books on topics related to heat island, solar energy and energy conservation in buildings. Guest editor of twelve special issues of various scientific journals. Coordinator of many international research programs and author of almost 230 scientific papers published in peer reviewed international scientific journals. Evaluator of research projects in 14 countries including USA, UK, France, Germany.

Afroditi SYNNEFA. Dr, is a Building and Environmental Physicist working as a research associate in the Group of Buildings and Environmental Studies at the National and Kapodistrian University of Athens (NKUA). Her research focuses on energy and environmental issues related to the built environment. She is the Technical Committee leader of the European Cool Roofs Council where she also acts as a consultant. She is the author of many papers published in international scientific peer reviewed journals and conference proceedings and she is a co-author of several chapters in international and national books.

Nyuk Hien WONG. Is professor in the Department of Building, National University of Singapore. He has been the Principal Investigator for a number of research projects funded by the various Singapore government agencies to study the Urban Heat Island effect in Singapore and to explore the various mitigation measures such as the effective utilization of urban greenery and cool roof materials. He also worked on Climate Change project looking into how Climate Change will affect the temperature profile in the urban context as well as the impact on energy consumption of buildings. Prof. Wong has been engaged as member of the advisory boards to the various government agencies in Singapore. Prof Wong has written or co-authored 11 books and published more than 300 international referred journal and conference papers in these related fields.

Michele ZINZI. Dr, staff researcher in the Technical Unit for Energy Efficiency of ENEA. Experienced in: building physics, testing of building envelope materials, methods and tools for energy efficient buildings. Author of many papers published in scientific journals and in international conferences. ENEA scientific responsible in several European Projects and IEA SHC tasks. National Executive Committee member in the Energy in Buildings and Communities Programme of IEA. 